\title{
The development of aggressive behaviour during childhood: What have we learned in the past century?
}

\author{
Richard E. Tremblay \\ University of Montreal, Canada \\ To the memory of Robert B. Cairns \\ (1933-1999)
}

\begin{abstract}
The major issues of the present appear to be, in large measure, the same ones that thoughtful contributors to the science (of behavioral development) had addressed in the past.
\end{abstract}

(Cairns, 1983, p. 90)

\begin{abstract}
Research on human aggression has been a flourishing industry in the 20th century. As the attention shifted from an instinctual paradigm to a drive paradigm and a social learning paradigm, what have we learned on the development of aggressive behaviour during childhood? Are children born with an aggressive instinct or do they have to learn to aggress? This question has deep philosophical roots, but it also has important practical implications. Should interventions prevent children from learning to aggress or should they help children learn to inhibit aggressive reactions? Since most of the 20th century work on the development of aggression was concentrated on adolescents and elementary school age children, there appeared to be an implicit assumption that aggression is learned during these developmental periods. It is argued that to understand the origins of aggressive behaviour and prevent chronic cases of physical aggression we will need to focus on the development of aggressive behaviour during the first few years after birth, and differentiate among forms of aggressive behaviour. The form of agressive behaviour that is generally considered more "serious" or "socially unacceptable" (physical aggression) is clearly ontogenetically antecedent to less "serious" forms of aggressive behaviour, such as verbal aggression or indirect aggression. Furthermore, as a rule the frequency of physical aggression appears to decrease with age. However, infants' physical aggression has generally not been considered developmentally significant. This is probably because of "the weakness of their limbs" and the apparent lack of "intentionality". To have a relatively complete description of the life-span developmental trajectories of human aggressive behaviour by the end of the 21 st century, we will need to start recruiting pregnant women very soon.
\end{abstract}

It is an interesting paradox that the more humans become "civilised" the more they appear to be preoccupied by violence. Research on the development and prevention of violent behaviour is a booming industry as we face the third millennium of the Christian era. Aggressive behaviour is central to most theories of human behaviour and is addressed by disciplines as varied as zoology, economics, and public health.

My original plan for this paper was to cover the development of theories, methods, and results of research on aggression over the past century. It quickly became obvious that at least one book, rather than a short paper, would be needed. As I struggled with the problem of defining which parts of aggressive behaviour research I would focus on, I realised that I could easily limit the paper to the problems related to defining the object of research. I have managed to go beyond this important preliminary step, but not much more because this review has confirmed my growing impression that we have been running ahead of ourselves.

To limit the scope I concentrated my attention on the origins of aggressive behaviour. In his paper on the history of developmental psychology, Cairns (1983) reminds us that many 19th-century students of animal and human behaviour explicitly stated that a clear understanding of behaviour required the description of behaviour development from conception onwards. In fact, a large part of the 1820 s Cuvier-Geoffroy debate concerning the origin of species, described at the time by Goethe as a volcanic eruption, was sparked by Geoffroy's decision to compare the development of fetuses rather than to continue comparing the anatomy of adult
Correspondence should be addressed to Richard E. Tremblay, GRIP, University of Montreal, 3050 Edouard-Montpetit, Montreal, H3T 1J7, Quebec, Canada; email: gripret@ere.umontreal.ca.

I thank Bill Hartup and Lea Pulkkinen for their extremely useful comments on a previous version of this paper. The following institutions have supported my work on the development of antisocial behaviour: the Canadian Donner Foundation, the Canadian Institute of Advanced Research, le Centre de Recherche Fernand-Seguin, le
Conseil Québécois pour la Recherche Sociale, les Fonds pour la Formation des Chercheurs et l'Aide à la Recherche du Québec, le Fonds pour la Recherche en Santé du Québec, the MacArthur Foundation, the Medical Research Council, the Molson Foundation, the National Consortium for Violence Research, the National Health Research Development Program, the Social Sciences and Humanities Research Council of Canada, the University of Montreal. 
animals (Appel, 1987). Von Baer's description of the development of fetuses during that period was integrated by Darwin in his evolutionary theory. According to Cairns (1983), Wundt rejected the developmental perspective arguing that the adult mind could be understood independently from the child mind. Wundt's and Cuvier's attitude to behaviour development appears to have prevailed in the study of aggressive behaviour over the past century. Adult aggressive behaviours were studied without reference to childhood aggressive behaviours. Adolescent aggressive behaviours were studied as if they emerged during adolescence, and most specialists of the early development of aggressive behaviours concentrated on the school years.

\section{What do we mean by the development of aggressive behaviour?}

\section{Aggressive or antisocial behaviour}

To understand what we have learned and what we need to learn, we first need to agree on the topic. What is aggressive behaviour? Judging from the lack of attention to the definition of aggressive behaviour in numerous research papers, it may come as a surprise to many that the major problem with the field could be a problem of definition. We have been putting our finger on this problem over and over again (e.g., Berkowitz, 1962; Burt, 1925; Buss, 1961; Cairns, 1979; Coie \& Dodge, 1998; Hartup \& de Wit, 1974; Parke \& Slaby, 1983; Pitkänen, 1969), but it regularly comes back to haunt us. The problem is so obvious that in the 1985 edition of the American Heritage Dictionary it is written: "Though the verb aggress has a long and honorable history, it has lately come to be associated primarily with the jargon of psychology and is often objected to".

In the last 20th-century edition of Carmichael's Handbook of Child Psychology, the reviewers of research on aggressive behaviour chose to break with the tradition of previous reviewers who had limited their discussion to research on aggression. Coie and Dodge (1998) decided to broaden the review to antisocial behaviour and conduct disorder because "the comorbidity of aggression with other antisocial behaviors suggests that an understanding of the etiology and developmental course of aggression might be enhanced by including aggression into the broader class of antisocial behavior" ( $p$. 781). This decision is congruent with the way childhood and adolescent aggressive behaviour has been studied during the last quarter of the 20th century. However, the decision must have been made with some hesitation, as the title they chose for the chapter was not "Antisocial behavior", but rather "Aggression and antisocial behavior". An equivalent title in the science of botany would be "Apples and fruits"!

The aggregation of different types of aggressive behaviours, and the aggregation of aggressive behaviours with different forms of antisocial behaviour clearly creates an important problem for a developmental science aiming to understand the origin and development of these behaviours. This problem can be observed by examining the context of the "aggression" scales which have been used over the past decades. The content of the scales defines what we are measuring and most of the popular scales contain a mix of behaviours that range from physical aggression to attention seeking and disobedience. Consider the following items from one of the most frequently used "aggressive" rating scale for parents (Achenbach \& Edelbrock, 1983): argues, brags, demands attention, disobeys, poor peer relations, jealous, lies, shows off, stubborn, moody, sulks, loud. The common denominator of these items appears to be that they can be annoying. To the extent that an annoying or irritating person causes discomfort to others, and to the extent that "aggressive" means someone who causes discomfort to others, we could conclude that that person is "aggressive". But, should we classify such children in the same "aggressive" category as those who physically attack? The Achenbach and Edelbrock (1983) "aggressive" scale has 23 items with only two that refer clearly to physical aggression, and two others that could be interpreted as physical aggression. Such scales are regularly used to identify either "aggressive", "externalising", "conduct problem", or "antisocial" individuals in clinical practice. They have also been used to identify genetic influences on phenotypes that are alternatively referred to as "aggressive", "externalising", "conduct disordered", or "antisocial" (e.g., Eley, Lichenstein, \& Stevenson, 1999; O'Conor, McGuire, Reiss, Hetherington, \& Plomin, 1998; Slutske et al., 1997).

Peer rating "aggression" scales were created with the procedure used to create the parent rating scale described earlier (i.e., factor analyses of large pools of items). They led to similar results. The "aggression" scale for one of the few large longitudinal studies specifically aimed at understanding the development of aggressive behaviour (Huesmann, Eron, Lefkowitz, \& Walder, 1984; Lefkowitz, Eron, Walder, \& Huesmann, 1977) includes the following items: disobeys teacher, gives dirty looks, makes up stories and lies, does things that bother others, gets in trouble. Only two of the ten items could be interpreted as physical aggression: starts fights, pushes and shoves. One of the important problems with defining aggressive behaviour is to identify its different forms of expression and to differentiate them from other phenomena that are associated, but are different. For example, hyperactivity and opposition are highly associated with physical aggression (Nagin \& Tremblay, 1999; Pulkkinen \& Tremblay, 1992), but their aggregation is unlikely to lead to a better understanding of the development of each of these types of behaviours, and unlikely to lead to a better understanding of their association.

Aggressive behaviour and antisocial behaviour are often aggregated probably because research on the development of aggressive behaviour has concentrated mainly on behaviours which are socially undesirable. This would explain why "aggression" scales would include behaviours, such as sulking, bragging, moodiness, which are clearly not antisocial, but are generally felt to be disruptive in a social context. Indeed, Coie and Dodge (1998) suggest that in the decade preceding the publication of their chapter, research on individual differences in aggression "led to the recognition that aggressive behaviors often occur in a context of other antisocial behaviors, including noncompliance with adults, delinquency, substance abuse, cheating, early and risky sexual activity, and vandalism" (p. 781) [my italics]. It should be noted here that the definition of antisocial behaviour has been expanded to include substance abuse and risky sexual activity, which often mean getting drunk and not using condoms.

Is aggressive behaviour always antisocial? Is the aim of research on aggressive behaviour to prevent the development of aggressive behaviour in the human species? These apparently naive questions highlight the importance of clearly defining what we mean by aggressive behaviour and aggression. Most parents would be proud to hear their child described as an 
aggressive tennis player. Most sales managers want aggressive salesmen. Most political parties want leaders who can be aggressive when needed. Do we label someone aggressive because he/she resorts to aggression? What do we consider an aggression?

Studies of aggressive behaviour in animals other than humans have tended to use definitions based on the characteristics of the behaviour of the aggressive individual (i.e., topographical qualities of the behaviour rather than effect of the behaviour on the "victim") (Hartup \& deWit, 1974). On the other hand, the most frequently used definition for research on the development of human aggressive behaviour over the last half of the 20th century is a "moral" judgement approach where an observer decides that the behaviour he observed was or was not intended to be "harmful to another person".

\section{Intent to harm}

We will come back to the concept of socially desirable aggressive behaviour. For the moment, let us concentrate on socially undesirable aggressive behaviour. Two recent reviews of research on aggressive behaviour in children and youth chose definitions that refer to the negative effect of the action on the "victim". Loeber and Stouthamer-Loeber (1998) chose a definition that refers to the negative impact of the act on the victim, without reference to intent: "aggression is defined as those acts that inflict bodily or mental harm on others" (p. 242). Coie and Dodge (1998) endorsed the Parke and Slaby (1983) definition that refers to the possible negative consequence of the act, but stresses the intent: "behaviour that is aimed at harming or injuring another person or persons" ( $p$. 550). Attribution of intent is particularly important when human aggression is considered socially defined. The methodological consequence to this decision is that research on human aggression must rely on the social judgement of an observer for "intent to harm" (e.g., Bandura, 1973; Walters and Parke, 1964).

With this approach, the observer is expected to take into account a multitude of factors, including cultural norms, antecedents of the aggressive act, and consequences, in order to determine if there was intent to harm. Interestingly, although a major part of the research on children's aggressive behaviour over the past two decades was inspired by a social learning approach, the majority of the studies did not rely for assessment on judges' attribution of intent to harm or injure. Most studies used ratings by adults or peers on items that described behaviours the investigator had, a priori, labelled "aggressive": hits, gives dirty looks, fights (e.g., Cairns, Cairns, Neckerman, Ferguson, \& Gariépy, 1989; Crick \& Grotpeter, 1995; Dodge, Lochman, Harnish, Bates, \& Pettit, 1997; Huesmann, Eron, Guerra, \& Crawshaw, 1994; Nagin \& Tremblay, 1999). Direct observation studies were influenced by animal behaviour studies and generally used behaviour coding procedures which minimise raters' attribution of intent (Archer \& Browne, 1989; McGrew, 1972; Patterson, 1982; Rubin, Hastings, Chen, Stewart, \& McNichol, 1998; Strayer \& Strayer, 1976).

The "intent" criteria is especially problematic for studying the development of aggressive behaviour during early childhood. For example, Kagan (1974) argued "that a young child cannot be aggressive until he has some psychic intention of injuring another" (p. 109). He concluded that aggressive behaviour defined in this way started "well into the second year" after birth, when a child can "put himself into the psychic state of another". One can easily imagine what would happen to research on aggressive behaviour in nonhuman animals if such a criteria were used. Does a dog intend to hurt when it bites another dog that tries to take its food away? Does a 12-month-old boy intend to hurt when he hits the peer who grabbed the toy in his hand? The age of "onset" of intent may have been clear to Kagan in 1974, but it is still a subject of debate (Diamond, Werker, \& Lalonde, 1994; Flavell \& Miller, 1998; Zelazo, Helwig, \& Lau, 1996). The intent criteria is not only a problem for infants and nonhuman animals. Anger and fear lead to reactions which are clearly not under the control of one's will. It could be argued in fact that many, if not most of the aggressive behaviours following intense frustration are impulsive behaviours that were not intended. Gray (Gray, 1971, 1982) proposed that a "fight-flight system" controlled the behavioural reactions to unconditioned punishment and nonreward. Lewis, Alessandri, and Sullivan (1990) showed that 4-month-old babies clearly expressed facial anger reactions to frustrations. These same reactions are expressed more clearly by the limbs of children a few months later when motor maturation enables the child to hit and kick.

The careful description of the development of aggressive behaviours during early childhood should help understand the social and moral value of these behaviours. If we, a priori, decide that aggressive behaviours cannot exist before a given age we, of course, prevent the falsification of the hypothesis. Similarly, if we start by taking a moral stance to define aggressive behaviour, we bias our observations. I recently attended a meeting of international investigators on children's antisocial behaviour, where it was argued that for fear of public reaction we should not say that children younger than 7 years of age behave in ways that would be legally considered an offence if they were older.

\section{Conclusion}

More than a quarter of a century ago, Hartup and deWit (1974) concluded their discussion on the definitions of aggression by recommending that investigators adjust definitions to the problem they want to address. This recommendation was made after they had observed that investigators' definitions of aggression were too general. Bandura (1973) made the same recommendation: "A high degree of specificity is required at the investigatory level because there is little reason to believe that the diverse activities subsumed under the omnibus label 'aggression', though sharing some ingredients in common, have the same determinants"' (p. 11).

It is difficult to understand why research on the development of aggressive behaviour went in the opposite direction in the quarter century that followed these recommendations. Investigators not only aggregate largely different forms of behaviours that have traditionally been considered "aggressive", but they also tend to aggregate aggressive behaviours with socially disruptive behaviours such as opposition and hyperactivity, with illegal activities such as smoking marijuana, and health-related risky behaviours such as not using a condom.

There were, of course, some exceptions to the general rule. For example, Cairns and Cairns (1984) stimulated the focus on physical aggression. Among others, they were followed by Coie, Dodge, Terry, and Wright (1991), Haapasalo and Tremblay (1994), Loeber and Hay (1997), Loeber, Tremblay, 
Gagnon, and Charlebois (1989), Nagin and Tremblay (1999), and Tremblay et al. (1991). Pulkkinen's (Pitkänen, 1969; Pulkkinen, 1983, 1987) pioneering work on offensive and defensive aggression was followed by Day, Bream, and Pal (1992), Dodge and Coie (1987), Dodge et al. (1997), and Vitaro, Gendreau, Tremblay, and Oligny (1998). Olweus $(1978,1993)$ initiated the work on bullying and was followed among others by Farrington (1993), Pepler, Craig, and O'Connell (1999), Schwartz, Dodge, and Coie (1993), and Smith and Sharp (1994). The importance of differentiating types of aggression can be seen very clearly in the comparisons of female and male aggression. Most studies of sex differences in human aggression up to the late 1980 s concluded that males became much more aggressive than females after early childhood (e.g., Feshbach, 1970; Hartup, 1974; Maccoby \& Jacklin, 1974, 1980). Following the work on indirect aggression among nonhuman female primates (see Hrdy, 1981; Hrdy \& Williams, 1983), Lagerspetz, Björkqvist, and Peltonen (1988) showed that 11- and 12-year-old girls had higher levels of indirect aggression than boys. These results were confirmed by a number of studies with younger and older subjects in different cultures: for example, Crick, Casas, and Ku (1999), Crick and Grotpeter (1995), Grotpeter and Crick (1996), Björkqvist, Österman, and Kaukiainen (1992), and Tremblay et al. (1996). Figure 1 is reproduced from the doctoral thesis of Lea Pulkkinen (Pitkänen, 1969). It clearly illustrates the different dimensions which some of the later work on aggression has attempted to assess, mainly during the school years.

\section{Onset of aggressive behaviour and increase in seriousness}

\section{Onset}

The recent use of the word "onset" in studies of antisocial behaviour illustrates the strong impact the developmental perspective has had in this area of research during the last decades of the 20th century. "Onset" has become one of the most fashionable words in the fields of developmental psychopathology and developmental criminology (e.g., Amer-

\section{Intensity}

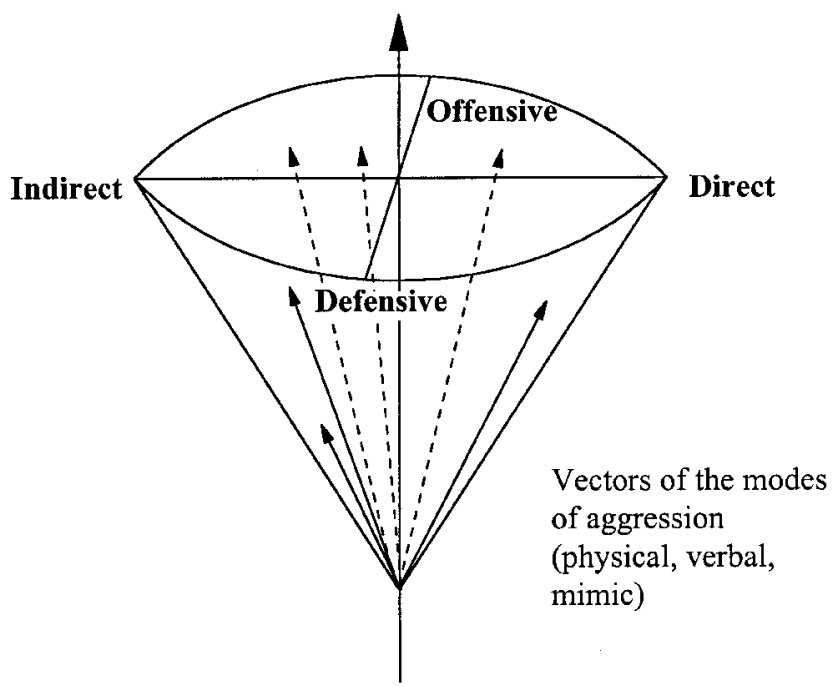

Figure 1. A descriptive model of aggression. (From Pitkänen, 1969.) ican Psychiatric Association, 1994; Farrington \& Hawkins, 1991; Farrington et al., 1990a; Lahey et al., 1998; Loeber, Stouthamer-Loeber, \& Green, 1991; Moffitt, Caspi, Dickson, Silva, \& Stanton, 1996; Tremblay, Pihl, Vitaro, \& Dobkin, 1994). It can be used to describe the start of a phenomenon which has a relatively short duration (e.g., onset of a cold, onset of a panic attack). From a developmental perspective the word "onset" generally refers to the age at which an individual first starts to engage in a type of behaviour that will persist for a relatively long period of time. For example, we can talk of age of onset of standing on two feet without support, age of onset of using words, age of onset of walking and running, age of onset of self-awareness, etc. In criminology, the developmental perspective has led to the concepts of onset, participation, escalation, desistance, termination, and duration to describe criminal careers (see Blumstein, Cohen, Roth, \& Visher, 1986; Farrington, Loeber, \& Van Kammen, 1990b; Loeber \& Hay, 1997; Nagin \& Land, 1993). The American Psychiatric Association (1994) introduced the concept of early and late onset conduct disorder for children in its latest version of the Diagnostic and Statistical Manual of Mental Disorders. The early onset form (i.e., before 10 years of age) appears to be characterised by physical aggression (Lahey et al., 1998).

In their review of misconceptions concerning the development of aggression, Loeber and Stouthamer-Loeber (1998) conclude that "the age of onset of aggression in male populations is not concentrated only in the preschool years" (p. 246) [my italics]. They present data from their longitudinal study of boys from Pittsburgh which indicate that less than 5\% of the boys had "onset" of minor aggression before age 5 years, whereas close to $40 \%$ had onset of minor aggression by 13 years of age (Figure 2). These results confirm the general impression that as children grow older they become more physically aggressive. In his presidential address to the American Society of Criminology, Elliott (1994) presented similar results from a longitudinal study of a random sample of US adolescents showing an increase in violent offending for boys and girls from 12 to 17 years of age.

The apparent rapid increase in deviant behaviour during adolescence, which is followed by an equivalently rapid decrease, has been labelled the age-crime curve (e.g., Farrington, 1986). It was described by the Belgian mathematician-astronomer-biosocial scientist Adolphe Quetelet in his 1833 book "Research on the Propensity for Crime at Different Ages" (Figure 3). Quetelet concluded that "Age is without contradiction the cause which acts with the most energy to develop or moderate the propensity for crime. This fatal

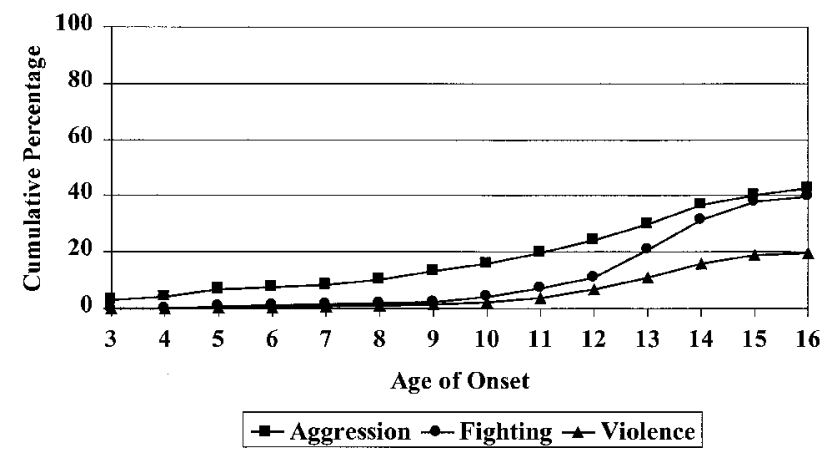

Figure 2. Cumulative age of onset of different forms of aggression in the oldest sample of the Pittsburgh Youth study. (From Loeber \& Stouthamer-Loeber, 1998.) 


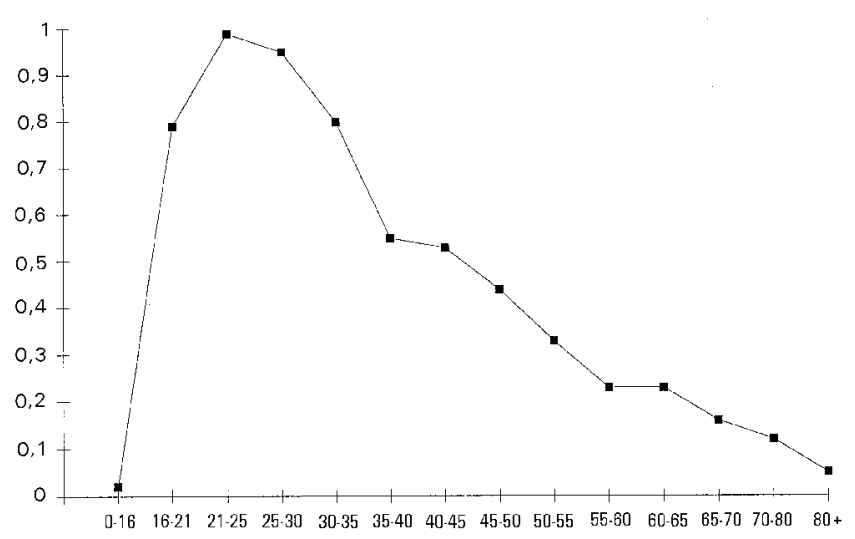

Figure 3. The male age-crime curve. (From Quetelet, 1833.)

propensity seems to develop in proportion to the intensity of physical strength and passions in man" (p. 65). Late 20thcentury scientists have suggested that the rise in testosterone levels during adolescence explained both the increase in strength and in physically aggressive passions (e.g., Ellis \& Coontz, 1990; Eysenck \& Gudjonsson, 1989). The alternative explanation has, of course, been environmental. As children become older they are increasingly influenced by their environment, and are thus more likely to learn to aggress from such bad environmental influences as deviant families, deviant peers and the media (e.g., Dishion, Patterson, Stoolmiller, \& Skinner, 1991; Eron \& Huesmann, 1986; Farrington, 1998; Huesmann \& Miller, 1994; McCord, 1991; Patterson, 1982; Vitaro, Tremblay, Kerr, Pagani-Kurtz, \& Bukowski, 1997).

The social learning approach to the development of aggressive behaviour has had a strong influence since Bandura (1973) rallied the troops in reaction to the classic ethological perspective published by Konrad Lorenz a decade earlier. The English translation of the book On aggression (Lorenz, 1966) was a bestseller in North America. In this book, Lorenz relied heavily on a phylogenetic perspective to convince readers that man had inherited an instinct for aggression which he needed to learn to control to prevent self-destruction. Surprisingly, he did not pay much attention to the ontogenetic perspective. His prescriptions to prevent the perversions of the aggressive instinct appear to target mainly the behaviour of adults.

Whereas Lorenz argued that humans were naturally aggressive and had to learn ways to control these aggressive tendencies, Bandura argued that humans learned to aggress. $\mathrm{He}$ started his book by prescribing the developmentalist approach: "A complete theory of aggression, whatever its orientation, must explain how aggressive patterns of behavior are developed" (p. 43). In the next chapter, logically titled "Origins of aggression", he described experiments with nursery school children showing that they imitated adults who physically and verbally aggressed inflated dolls. These experiments appeared to satisfy Bandura's requirement to "explain how aggressive patterns of behavior are developed". He concluded that the origin of aggression in man was social learning. Surprisingly, there is no reference in the book to the work on aggressive behaviour in infants and toddlers by child development pioneers, such as Bridges (1931), Dawe (1934), and Goodenough (1931), which were still cited at the end of the 20th century.

It is useful here to recall that this debate among 20thcentury scientists is not a new debate in the history of mankind.
The social learning view of antisocial development was very clearly described more than two hundred years earlier by JeanJacques Rousseau (1762/1979). The first phrase of his child development handbook Émile, makes the point very clearly: "Everything is good as it leaves the hands of the Author of things; everything degenerates in the hands of man" (p. 37). A few pages later he is still more explicit and appears to be writing the agenda for 20th-century developmental psychopathology: "There is no original sin in the human heart, the how and why of the entrance of every vice can be traced" (p. 56). Rousseau's strong stance was in clear opposition to Hobbes' description of young children as selfish machines striving for pleasure and power, and wicked men as children who had not grown up (Hobbes, 1647/1998, 1651/1958; Rousseau, 1762/1979).

This debate has far-reaching consequences, not only for child development investigators and educators, but also for political scientists, philosophers, and law makers. Because the underlying debate is clearly our view of human nature, it is not surprising that investigators are likely to prefer the "origin of aggressive behaviour" that best fits their view of human nature, and their political commitment. In hindsight, it is easy to understand why a man, who had serious problems living in the pre-revolutionary France he wished to conquer, would chose to highlight the negative impact of civilisation. It is less clear, however, how a man who put his five children in an orphanage as soon as they were born, and does not appear to have had much contact with children, had such a powerful impact on two centuries of children's education (Cranston, 1983). It is still more surprising that with all the systematic studies on child development and on aggression since Rousseau wrote Émile, we still do not clearly understand the development of aggressive behaviour in the early years. This was a conclusion reached by Hartup and deWit (1974) a quarter of a century ago, and the progress made can be measured by the fact that Coie and Dodge (1998) had to refer to a cross-sectional study of 11 infants and 13 toddlers published almost 70 years ago (Goodenough, 1931) to briefly allude to the development of physical aggression in early childhood. Rousseau was convinced that "whoever obeys conscience walks in the true path of nature and need not be afraid of being mislead" (Cranston, 1991). It appears that 20th-century investigators looking for the origins of aggression believed that they could not be mislead by the age of the subjects they studied, as long as they conducted longitudinal and experimental studies.

\section{Increase in seriousness}

Systematic and unsystematic observations of single cases had long led philosophers (e.g., Hobbes, 1651/1958; Locke, 1693/ 1996) and child specialists (e.g., Sully, 1895) to the conclusion that young children react with anger, physically aggress, and need to be socialised. Part of the confusion concerning the concept of "onset" appears to come from the concept of "seriousness". Physical aggression is usually considered the most serious form of aggression. Courts will generally sanction more severely a physical aggression than a verbal one. Teachers and parents are more likely to do the same when they have to sanction a child who hit another and one who gave "dirty looks". Both observational data from small samples of children (Bridges, 1931; Dawe, 1934; Goodenough, 1931; Hartup, 1974; Murphy, 1937; Restoin et al., 1985; Strayer \& Strayer, 1976; Strayer \& Trudel, 1984) and recent parent reports, and self-reports of large samples (Choquet \& Ledoux, 1994; 
Tremblay et al., 1996; Tremblay et al., 1999a) indicate that children start by physically aggressing during infancy and go on to verbal aggression once they have learned to talk.

Figure 4 represents mothers' ratings of age at onset of physical attacks for a sample of 112 children assessed at age 17 and 30 months in a population survey of families in Québec. At both points in time the mothers were asked if their child physically attacked others. If the response was positive we asked the age of the child when he first physically attacked someone. This is the same procedure that Loeber and Stouthamer-Loeber (1998) used to collect data on age of onset of physical aggression with 13-year-old boys. Results show that $20 \%$ of mothers report that their 17 -month-old child physically attacks others. By 30 months of age $25 \%$ of the children are reported to physically attack. This retrospective information indicates that some children initiate these behaviours towards the end of the first year after birth, whereas others start during the second and the third year. The cumulative age of onset of physical aggression curves mirror those in Figure 2, but with major age of onset differences. The Pittsburgh data collected at 13 years of age indicated that less than $5 \%$ of 3 -year-olds had initiated minor physical aggressions. The Québec data indicate that $80 \%$ of the children are reported by their mothers to use some form of physical aggression by 17 months of age (Tremblay et al., 1999a). These major differences in the identification of age of onset of physical aggression are probably due largely to the use of a retrospective procedure to collect the data on age of onset. Figure 4 shows that although $20 \%$ of the mothers report physical attacks at 17 months of age, when they are asked the same question at 30 months, less than $5 \%$ recall that their child had started to physically attack by 17 months. The recall problem will clearly be greater when these mothers or their child will be asked to recall age of onset during adolescence.

Parent reports in a sample of more than 22,000 children representative of the population of 0 - to 11 -year-old children in Canada in 1994 indicate that although the frequency of physical aggression decreases from the third to the eleventh year of life, indirect aggression increases from 4 to 8 years of age (Tremblay et al., 1996). We will, of course, need longitudinal studies to confirm that these results represent intra-individual change. However, at the group level, the form of aggressive behaviour that is generally considered more "serious", or "socially unacceptable" (physical aggression) is clearly ontogenetically antecedent to less "serious" forms of aggressive behaviour, such as verbal aggression or indirect aggression. The exciting work that needs to be done is to study the developmental trajectories of these aggressive behaviours at the intra-individual level during infancy and toddlerhood, and their relationship with later development. This work should be as challenging as the work on brain development during the first years of life (see Cynader \& Grost, 1999).

Interestingly, the "onset" of physical aggression during infancy is often not accepted as a "valid age of onset" either because it does not meet the criterion of "intentionality" or the one of "harm to the victim" of the aggression. I believe that these two objections are the result of what I will call a human adult biased view of child development. The human, or anthropomorphic bias, was discussed earlier: Infants cannot intend to aggress, thus physical aggressions at that age does not count as onset as it would for puppy dogs.

The harm to the victim criterion is the "adult" part of the bias. The literature on delinquency, antisocial behaviour, and aggression generally uses the term "serious" to qualify the harm done to the victim. Infants who hit adults do not hurt adults, thus it is not an aggression. When infants seriously hurt, the behaviour is attributed to an accidental act. For example, in the case of a serious bite during a fight for a toy the aggressive behaviour will be attributed to a rage provoked by the pain of growing teeth. Infants kick, hit, bite, throw objects at others and will use objects to hit others. Most parents and daycare personnel know this, and thus give plastic toys, hide objects that could be used to hurt seriously, and supervise groups of infants.

St. Augustine of Thagaste may have written the most sensible page on this topic 1600 years ago. In the seventh chapter of the first book of his Confessions he describes the physical aggressions of infants and concludes: "Thus it is not the infant's will that is harmless, but the weakness of infant limbs .... These things are easily put up with; not because they are of little or no account, but because they will disappear with increase in age. This you can prove from the fact that the same things cannot be borne with patience when detected in an older person" (St. Augustine, 1960, pp. 49-50). Hobbes, in De Cive,

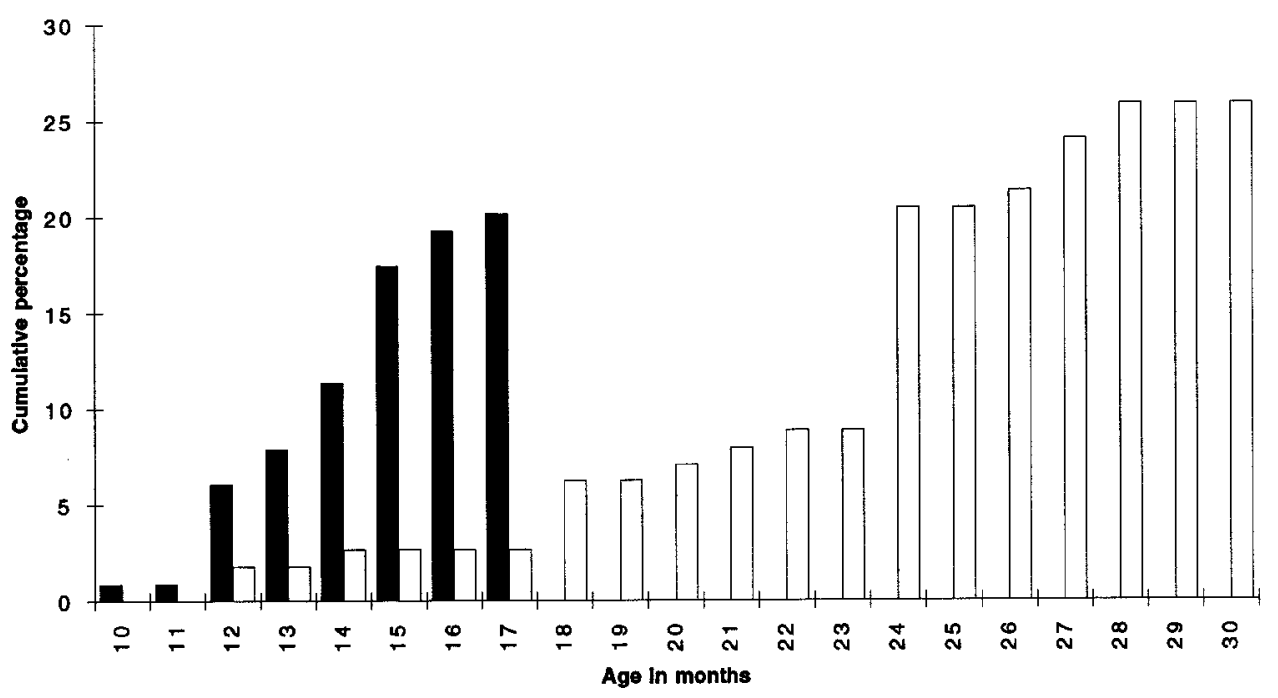

Figure 4. Age of onset of physical aggression. 
makes a similar statement when he refers to a wicked man as a robust child. Clearly, we cannot identify the origins of aggressive behaviour by focusing on the consequences of the acts. The focus on the severity of the consequences of aggressive behaviours is a legitimate area of study, but differs from the study of the origins of aggressive behaviour. These two areas should lead to different measuring instruments.

\section{How stable is aggressive behaviour?}

The strong interest in the stability of aggressive behaviour in the last half of the 20th century preceded the search for the age of onset. Olweus (1979) published one of the most often cited reviews of research on the stability of aggressive behaviour. Based on longitudinal data (time 1 to time 2) from 16 samples of males, he concluded that aggressive behaviour was as stable as intelligence. A similar review of the possibly hundreds of time 1 to time 2 correlations of aggressive behaviour scores that have been published since the Olweus review would most probably lead to the same conclusion. Two studies starting towards the end of infancy indicated that stability of physical aggression was already high in the preschool years (Cummings, Iannotti, \& Zahn-Waxler, 1989; Keenan \& Shaw, 1994).

The meaning of these results for understanding the ontogeny of aggressive behaviour can be appreciated only if we recognise the form of stability which is being assessed. A high correlation between two assessments indicates that at two points in time individuals retain a relatively consistent placement within the group. Correlational analyses of the stability of aggressive behaviour with longitudinal data do not give information on intra-individual change in aggressive behaviour over time. Parke and Slaby (1983) did not appear to realise this when they introduced their discussion of the Olweus (1979) review by referring to "the extent to which aggression is stable within individuals over time" (p. 573). They went on to caution the reader that high stability of aggression ratings did not mean good predictability, as Farrington (1978) had high rates of false positive and false negative cases when he tried to predict interpersonal violence at 21 years of age from age 10 years teacher ratings of how a child is difficult to discipline. This is an excellent example of how easy it is to generalise words such as "aggression" and "stability". Because global assessments of "aggressive" behaviour at two points in time are highly correlated does not mean that assessment of a given form of aggressive behaviour at time 1 (e.g., disobedience in class) will accurately predict another form of aggressive behaviour at another point in time (e.g., arrests for physical violence). This is one of the reasons why the use of global scales of aggression, antisocial behaviour, and delinquency have thwarted our ability to move the field beyond the puzzling statement that aggression, antisocial behaviour, and delinquency are highly stable phenomena without much predictive accuracy.

The concept of stability measured by relative position to others on an aggression scale is very different from the concept of stability measured by comparing the absolute level of aggression an individual has at two or more points in time. For example, different methodologies will be needed to answer the following two questions: (a) Did Paul increase the frequency of his physical aggressions from 2 to 15 years age? (b) Was Paul more aggressive than Luc at 2 and 15 years of age? Much of the research on aggressive behaviour in the latter half of the 20th century used a methodology that could address only the latter question. Although many studies were trying to find the age of onset of aggression, very few attempted to describe the absolute changes in the development of specific forms of aggression.

One notable exception was a longitudinal study by Cairns and colleagues (1989) in which annual assessments of physical aggression were used to describe the changes in the frequency of physical aggression for boys and girls from grade 4 to grade 12. Their results clearly showed that contrary to the age-crime curve discussed earlier, the frequency of physical aggression decreased systematically with age. Unfortunately, there do not appear to be similar studies during the preschool period which would enable us to understand the absolute stability of different forms of aggression during these years of rapid change. Similar studies on forms of aggressive behaviour other than physical aggression would also be useful to understand how physical aggression is transformed into more socially acceptable aggressive behaviours. We in fact have almost no knowledge of the development of socially positive aggressive behaviour (Pulkkinen, 1996).

The description of mean levels of a given type of aggressive behaviour for a given population over time is only a first step in understanding the ontogeny of aggressive behaviour. Most of the developmental work on aggressive behaviour has been based on the "variable approach" where the variable is the main unit of analysis (e.g., the mean scores of a variable measured at two or more points in time are compared or correlated). An alternative strategy is the "person approach" where the person is the main unit of analysis (Block, 1971; Cattell, 1965; Magnusson \& Bergman, 1988). The aim of the analysis is to go beyond the mean of the group and identify categories of developmental trajectories. A number of suggestions have been made over the past decade concerning different trajectories or pathways leading to deviant forms of social development (e.g., Loeber, 1988; Moffitt, 1993; Patterson, DeBaryshe, \& Ramsey, 1989), but appropriate statistical procedures to test these hypotheses have been lacking.

Nagin and Land (1993) devised a statistical procedure to study different types of criminal careers that appears to be a promising tool for identifying developmental trajectories. Applied to repeated measures of physical aggression on a large sample of boys followed from 6 to 15 years of age, the procedure enabled Nagin and Tremblay (1999) to identify four developmental trajectories of physical aggression. The four groups had four different levels of physical aggression in kindergarten (Figure 5). The group with the highest level was the smallest (4\%) and maintained that level up to age 15 .

Similar results were obtained when Broidy, Nagin, and Tremblay (1999) used the same type of analysis with two datasets from New Zealand (Fergusson, Lynskey, \& Horwood, 1996; Moffitt et al., 1996), one other dataset from Canada (Pagani, Boulerice, Tremblay, \& Vitaro, 1997), and two datasets from the USA (Dodge et al., 1997; Loeber, Farrington, Stouthamer-Loeber, \& Van Kammen, 1998). This technique can be used to study trajectories of different types of behaviour simultaneously. This will enable investigators to describe how two or more forms of aggressive behaviour develop differently over time in different groups of subjects. For example, one would expect to observe that some of the most physically aggressive infants would substantially reduce their use of physical aggression but increase their use of verbal aggression, others would reduce physical aggression and 


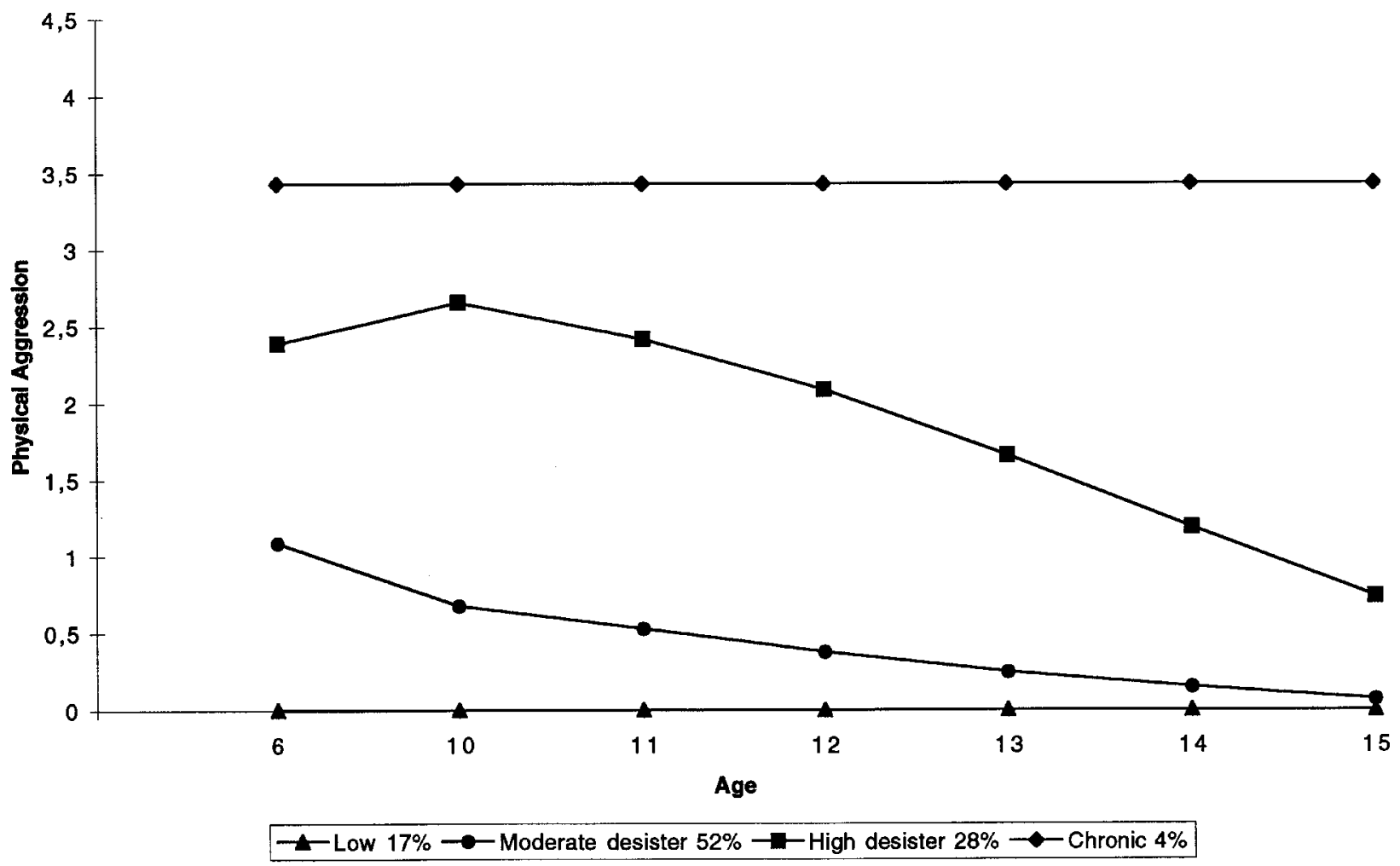

Figure 5. Trajectories of physical aggression for boys aged 6 to 15 years.

increase indirect aggression, and still others would reduce physical aggression and not go on to engage in much verbal or indirect aggression. Understanding these different developmental trajectories will be extremely important to plan interventions that would help individuals follow trajectories leading to the prosocial use of their proneness to aggressive behaviour. Other recent statistical developments will also help in analysing developmental data on aggressive behaviour (e.g. Bryk \& Raudenbush, 1987; Clogg, 1995; Goldstein, 1995; Willett \& Sayer, 1994).

The major problem in pushing the field forward may not be one of sophisticated statistical procedure, but more a problem with having the appropriate data. There are very few longitudinal studies which have collected data on aggressive behaviour from infancy onwards, and those who have may not have collected the appropriate data. Most large-scale longitudinal studies ask a small set of questions on numerous variables and the data collection points are generally not closer than a year apart. We may need longitudinal studies that specifically target the early development of aggressive behaviour. Such studies would need to have repeated measurements at least every two to three months from birth to 36 months and obtain frequency data on a large set of aggressive behaviours. Data collection from 3 years of age to adolescence would ideally be every 6 months. Such studies have been done during the elementary school years (e.g. Loeber et al., 1998) because funding agencies, such as the Office of Juvenile Justice and Delinquency Prevention of the US government, believed that youth violence could be prevented if we understood the early development of aggressive behaviour. To the extent that funding agencies understand that the "onset" of these problems is in the preschool years they should be willing to fund major projects to study the origins and development of man's aggressive behaviour.

\section{Understanding and changing the course of development}

Although aggressive behaviour during the first five years of life has not been studied enough to understand the early developmental course of different forms of aggression, the processes that lead to the different developmental courses, and their impact on the later developmental courses, much work in the last twenty-five years has attempted to understand the developmental processes leading to aggressive behaviour during the elementary school years and adolescence. Most of this work was inspired by the social learning model elaborated by Bandura (1973). Investigators focused on interactions within the family (e.g., Dumas \& Wahler, 1985; Patterson, 1982; Wahler \& Dumas, 1986), on interactions with peers (e.g., Boivin \& Vitaro, 1995; Coie et al., 1991; Dishion, 1990; Dodge \& Coie, 1987), and on the impact of the media (e.g., Eron, 1982; Huesmann \& Eron, 1986; Huesmann \& Miller, 1994).

The work of Patterson and his colleagues at the Oregon Social Learning Center (e.g., Patterson, 1982; Patterson, Dishion, \& Bank, 1984) is a good example of the short-term longitudinal studies using detailed direct observations in attempts to understand how family interactions influence the development of aggression. The investigators made repeated observations of the interactions among family members in families of pre-adolescents and adolescents referred for behaviour problems. The behaviours of family members, such as "disapproves, negative commands, dependent, destroys, humiliates, ignores, physically negative, and noncompliant", were recorded continuously during observation sessions by trained observers in the clinic or in the families' homes. Their conclusion from the analyses of thousands of hours of observations was that parents' management of children's 
behaviour reinforces aggressive behaviour (see Patterson, 1982; Patterson, Capaldi, \& Bank, 1991).

These studies made important methodological contributions to the observation of social interactions that trigger aggressive behaviours at a proximal level, but they also showed the enormous effort which would be needed to apply these methodological innovations to understand the long-term processes which lead to different developmental trajectories of aggressive behaviour. For example, because aggressive behaviours are relatively infrequent, especially in front of observers, the detailed observations of different types of negative behaviours were generally aggregated into a total score labelled TAB (total aversive behaviour), and publications often used the terms aversive, coercive, aggressive, and antisocial behaviour as synonyms: "We believe that reinforcement for aggression is provided directly in the interaction among family members. The antisocial behaviors then generalize from home to other settings, leading to social failures that in turn contribute to the long-term maintenance of the child in the antisocial process" (Patterson et al., 1991, p. 139). In all likelihood, the TAB score was created because it would have been too costly to collect enough data to obtain separate reliable estimates of different forms of aggression (e.g., physical and verbal), and different forms of aversive behaviours which are not aggressions (e.g., disapproves, dependent, ignores, noncompliant). Although we may be able to get large enough grants to collect the necessary data, I wonder if we will be able to convince enough families to be observed in conditions that would generate that data. It may be easier to convince families with referred disruptive pre-adolescents to submit to these extended observational procedures than to convince the parents of infants needed to understand the origin of these processes and the intra-individual change during the preschool years and beyond.

In the 1980s, the social learning theory and cognitive theories were merged to create social information-processing models of aggressive behaviour (Dodge, 1986; Huesmann, 1988; Rubin \& Krasnor, 1986). These models were, like the family interaction studies described earlier, attempts to understand the proximal processes leading to an aggression. However, unlike the family interaction studies, the focus was not on behaviours that can be observed by the naked eye, but on the activity of the neurones in the subject's brain. Thus, subjects assessed as "aggressive" and "not aggressive" by adults or peers were asked to reveal how they would respond to hypothetical situations. Results have generally indicated that children labelled aggressive, conduct disordered, antisocial, and delinquent are less attentive to most social cues, more attentive to aggressive social cues, they make more frequent hostile interpretations of others' intentions, they generate less alternative responses to a specific situation, their alternative responses are qualitatively different, they respond more impulsively, and they tend to give a more positive value to an aggressive response (Coie \& Dodge, 1998; Dodge, in press).

Although the aim of these studies is meant to understand proximal causes of aggressive behaviours the results are often used as support of the social learning theory concerning the origins of aggressive behaviour. In his presidential address at the meetings of the International Society for Research on Aggression, Huesmann (1998) presented his informationprocessing theory of the development and instigation of aggressive behaviour and concluded: "Learning plays a key role in the acquisition of scripts, schemes, and emotional responses for aggression just as learning plays the key role in the acquisition of procedural and declarative knowledge. In particular, exposure to violence in the mass media and the real world play major roles in creating the cognitive and emotional structures that make aggressive behavior more likely in humans over the long run" (p. 9). If Konrad Lorenz had been present at that meeting he would certainly have asked how humans managed to dominate planet earth before they invented cinema and television!

The 20th century has been the century of longitudinal studies. Never in the history of mankind have we collected so much information on so many individuals to understand human development. Longitudinal studies are useful to describe the development of a phenomenon, but they cannot demonstrate causal processes. From this perspective, it is surprising to observe that most of the longitudinal studies of aggressive behaviour have been weak on describing the development of the phenomenon because of the different problems described earlier, whereas much energy was concentrated on testing hypotheses concerning proximal and distal causes with short-term and long-term longitudinal data. This is typical of a science which is trying to run ahead of itself.

The best way to address causal questions is through experiments. Longitudinal studies are the alternative when experiments are impossible, but causal questions never get satisfying answers from longitudinal studies. It is sometimes argued that longitudinal studies must be used with children because experiments are not ethical. We often forget that children are constantly the object of interventions which are guided more by instinct than by sound knowledge of child development. This is especially the case with children and youths who tend to be disruptive. Preventive and corrective interventions are generally given to these children, and ethical considerations would suggest that the choice of these interventions should be based on evidence of their effectiveness. The process by which we establish the effectiveness of these interventions should be experimental, and thus offer an excellent opportunity to test causal hypotheses. Interventions to help violent individuals or prevent the development of chronic trajectories of physical aggression offer the opportunity to test hypotheses concerning the causes of aggression while searching for effective ways to help at-risk individuals.

Most interventions to prevent or reduce aggression are not done within an experimental procedure, but a number of welldesigned randomised experiments with children to prevent the development of antisocial behaviour have been reported (e.g., McCord \& Tremblay, 1992; Tremblay \& Craig, 1995; Tremblay, LeMarquand, \& Vitaro, 1999b; Wasserman \& Miller, 1998). These studies have a long tradition. One of the first, and one of the best designed, the Cambridge-Somerville study (McCord, 1978, 1992; Powers \& Witmer, 1951), started in the 1930s. Although some of these studies have shown that interventions can have iatrogenic effects (Dishion, McCord, \& Poulin, 1999; McCord, 1978), some have shown long-term positive effects (e.g., Hawkins, Farrington, \& Catalano, 1998; Olds et al., 1998; Tremblay, Kurtz, Mâsse, Vitaro, \& Pihl, 1995; Vitaro, Brendgen, \& Tremblay, in press; Weikart \& Schweinhart, 1992). However, to my knowledge, none have shown a significant long-term impact on the most feared form of aggression. This may be because most have not used physical aggression as an outcome and, in keeping with the tradition of trying to address aggression in general, most of these intervention experiments did not specifically target 
physical aggression. Interventions with school-age children have targeted globally defined aggression, anger control, and disruptive behaviour (e.g., Hawkins et al., 1998; Kellam, Rebok, Ialongo, \& Mayer, 1994; Lochman, 1992; Tremblay, Mâsse, Pagani, \& Vitaro, 1996; Vitaro, Brendgen, \& Tremblay, 1999), whereas interventions with preschool children tend to target parenting skills and cognitive development (Olds et al., 1998; Schweinhart, Barnes, \& Weikart, 1993; WebsterStratton, 1998). Parent training addresses discipline issues and the use of physical punishment, but could focus more specifically on the regulation of physical aggression during the preschool years.

If the regulation of physical aggression is learned during the preschool years, one would expect that interventions specifically targeting this regulation during this sensitive period would prevent chronic trajectories of physical aggression and increase the likelihood of positive aggression. By targeting different hypothesised causal mechanisms, such as emotional regulation, executive functions, information processing, impulsivity, parental discipline, and peer influence, we could test these hypotheses more directly than we can with longitudinal studies, and simultaneously find the best preventive interventions.

\section{Conclusion}

As I was preparing to write this conclusion I learned of the untimely death of Bob Cairns. Twenty years ago Louis Gariepy had brought to my attention his 1979 book, Social Development: The Origins and Plasticity of Interchanges. Since that time the work of Bob and Beverley Cairns has been a constant source of inspiration. Bob Cairns did it all. He studied mice and men, he conducted longitudinal studies and experimental intervention, he zoomed in on physical aggression and moved back to consider the broader social development picture, he looked into the history of the field and he made methodological innovations. The reader who wants to study the best work on aggression in the second half of the 20th century will find most of it in the works of Bob Cairns.

Bob summarised the state of knowledge at the beginning of the century in the following way: "For whatever reasons, the information available about longitudinal development by the end of the first period (1912) of the era's history was either sketchy (e.g., Binet's study of his two daughters) or subjective and retrospective (e.g., psychoanalytic interviews)" (Cairns, 1983 , p. 68). Longitudinal studies started in the following period (1913-46) and increased linearly over the next half century. Unfortunately, except for a few longitudinal studies like the one conducted by Cairns and Cairns (1994), the progress made in understanding the developmental course of aggressive behaviour was much less than it could have been because of problems with the definition of aggressive behaviour and because the first years of development were not studied.

From that perspective there has been less progress made in understanding the development of aggressive behaviour than Mills (1899) expected a century ago when he recommended longitudinal studies of individuals from birth to maturity. However, the lack of adequate data has not prevented a proliferation of general and specific theories concerning aggressive behaviour. Cairns' comment on the theories at the beginning of the century can be applied to the theories at the end of the century: "it was on this fragmentary information that the most influential psychoanalytic and behavioristic theories of cognitive and personality development were formulated, and few data were available to assess their implications or correct their shortcomings" (1983, p. 68).

What should developmentalists do in the 21 st century to understand the development of aggressive behaviour? Well, my answer to this question will not come as a surprise to readers who have had the time and patience to read this essay from beginning to end. I hope that in $2100, I J B D$ will publish a review of the past hundred years of research on aggression in which the author will report that hundreds of studies, in dozens of cultures all over the world, will have followed the developmental course of different types of aggressive behaviours from the first year after birth to late adulthood for hundreds of thousands of subjects. The author of that essay should be in a position to describe numerous life-course developmental trajectories of aggressive behaviour replicated across cultures. He or she will probably remind the reader that developmentalists completed the basic descriptive work needed to understand the origin, development, and expression of human aggression almost a hundred years after geneticists completed the basic descriptive work of the human genome. He or she will certainly note that a complete description of the human genome was an easy task once the technology was available, while a lifespan description of developmental trajectories of aggression was less a matter of having the technology than the collective will, perseverance, and humility of the community of behaviour developmentalists to pool their resources and create large international longitudinal projects on the development of the key behaviour problems that have major impacts on health and well-being, and thus on the human, social, and financial capital of human societies. The author of that essay will also remind the reader that the study of genetic and environmental effects on aggressive behaviour could not be adequately studied until the phenotypes were well described. He or she will most certainly recall that at the end of the 20 th century and the beginning of the $21 \mathrm{st}$, there was a strong movement to study the genetic-environment correlations and interactions for social, cognitive, and emotional development (see Plomin \& Rutter, 1998; Rutter, 1996) which, concerning the development of aggression, was handicapped by an equally strong movement to aggregate all forms of socially obnoxious behaviours into fuzzy labels, such as "antisocial", "externalising", "disruptive". I also hope that the author of the essay will be able to report that important progress has been made in the prevention of chronic physical violence. I expect that he/she will remind readers that the major advances in preventing chronic physical violence were made through alliances of the large-scale longitudinal studies, described earlier, with service delivery agencies to experiment different types of prevention programmes at different periods of development. The author of that essay will certainly stress the fact that these experiments not only led to the identification of effective prevention programmes, but also to the identification of important causal factors of chronic aggression for certain types of individuals. My strongest conviction is that it will be reported that the most effective interventions were very intensive, started prior to birth (still better if before conception) and, in some cases included permanent support, similar to support for diabetics.

As I look forward to that $I J B D$ paper which will appear in 2100 , I have this very strong feeling that it is just around the corner, and that there will not be time to do all that needs to be done for my future colleagues to report all the important discoveries which I am expecting. I clearly remember that in 
1983 when we were planning the Montréal Longitudinal Experimental study, I sketched the data that needed to be collected up to 1990 and was told by a colleague to stop dreaming, we had data to collect in 1984 and there was plenty of time to think of 1990. During the early 1990s, the same phenomena occurred when we started planning data collection in 2000 and 2001. The next century, the next millennium, felt so distant! Well, they are here, and the next century is around the corner for those who want to understand the development of aggression from birth to maturity.

The major lesson I have drawn from this attempt to look back on a hundred years and onward for another hundred years is one of humility. We are very far from having one investigator, one research team, one study make a definitive contribution to our understanding of the development of aggressive behaviour. We need large, very large, collaborative efforts. Let us imagine that we will need a few years to convince people to invest in large international lifespan longitudinalexperimental studies. If such studies were to start in 2010, most of the babies born that year will possibly live to see the end of the 21st century. If the author of the $I J B D 2100$ review paper wants to meet the editor's deadline, which in the tradition set by Bill Hartup should be 1 December 2099, we need to hurry and start working hard on these collaborative studies.

Manuscript received October 1999 Revised manuscript received January 2000

\section{References}

Achenbach, T.M., \& Edelbrock, C. (1983). Manual for the child behavior checklist and revised child behavior profile. Burlington, VT: University of Vermont, Department of Psychiatry.

American Psychiatric Association (1994). Diagnostic and statistical manual of mental disorders (4th ed.). Washington, DC: Author.

Appel, T.A. (1987). The Cuvier-Geoffroy debate: French biology in the decades before Darwin. New York: Oxford University Press.

Archer, J., \& Browne, K. (Eds.) (1989). Human aggression: Naturalistic approaches. London: Routledge.

Bandura, A (1973). Aggression: A social learning analysis. New York: Holt.

Berkowitz, L. (1962). Aggression: A social psychological analysis. New York: McGraw-Hill.

Björkqvist, L., Österman, K., \& Kaukiainen, A (1992). The development of direct and indirect aggressive strategies in males and females. In K. Bjökqvist \& P. Niemelae (Eds.), Of mice and women: Aspects of female aggression (pp. 5164). San Diego, CA: Academic Press.

Block, J. (1971). Lives through time. Berkeley, CA: Bancroft.

Blumstein, A, Cohen, J., Roth, J.A. \& Visher, C.A (Eds.). (1986). Criminal careers and "career criminals". Washington, DC: National Academy Press.

Boivin, M., \& Vitaro, F. (1995). The impact of peer relationships on aggression in childhood: Inhibition through coercion or promotion through peer support. In J. McCord (Ed.), Coercion and punishment in long-term perspectives (pp. 183197). New York: Cambridge University Press.

Bridges, K.M.B. (1931). The social and emotional development of the pre-school child. London: Kegan Paul.

Broidy, L., Nagin, D., \& Tremblay, R.E. (1999). The linkage of trajectories of childhood externalizing behaviors to later violent and nonviolent delinquency. Paper presented at the Biennial Meeting of the Society for Research in Child Development, Albuquerque, NM.

Bryk, AS., \& Raudenbush, S.W. (1987). Application of hierarchical linear models to assessing change. Psychology Bulletin, 101, 147-158.

Burt, C.L. (1925). The young delinquent. London: University of London Press.

Buss, A.H. (1961). The psychology of aggression. New York: Wiley.

Cairns, R.B. (1979). The analysis of social interactions: Method, results and illustrations. Hillsdale, NJ: Lawrence Erlbaum.

Cairns, R.B. (1983). The emergence of developmental psychology. In P.H. Mussen (Ed.), Handbook of child psychology, (Vol. 1, pp. 41-102). Toronto: Wiley.

Cairns, R.B., \& Cairns, B.D. (1984). Predicting aggressive patterns in girls and boys: A developmental study. Aggressive Behavior, 10, 277-242.

Cairns, R.B., \& Cairns, B.D. (1994). Life lines and risks: Pathways of youth in our time. New York: Cambridge University Press.
Cairns, R.B., Cairns, B.D., Neckerman, H.J., Ferguson, L.L., \& Gariépy, J.L. (1989). Growth and agression: 1. Childhood to early adolescence. Developmental Psychology, 25, 320-330.

Cattell, R.B. (1965). The scientific analysis of personality. Chicago, IL: Aldine.

Choquet, M., \& Ledoux, S. (1994). Adolescents: Enquête nationale. Paris: INSERM.

Clogg, C.C. (1995). Latent class models. In G. Arminger, C.C. Clogg, \& M.E. Sobel (Eds.), Handbook of statistical modelling for the social and behavioral sciences (pp. 311-359). New York: Plenum.

Coie, J.D., \& Dodge, K.A (1998). Aggression and antisocial behavior. In W. Damon \& N. Eisenberg (Eds.), Handbook of child psychology: Social, emotional, and personality development (Vol. 3, pp. 779-862). Toronto: Wiley.

Coie, J.D., Dodge, K.A., Terry, R., \& Wright, V. (1991). The role of aggression in peer relations: An analysis of aggression episodes in boys' play groups. Child Development, 62, 812-826.

Cranston, M.W. (1983). Jean-Jacques: The early life and work of Jean-Jacques Rousseau, 1712-1754. London: Allen Lane.

Cranston, M.W. (1991). The noble savage: Jean-Jacques Rousseau, 1754-1762. Chicago, IL: University of Chicago Press.

Crick, N.R. (1995). Relational aggression: The role of intent attributions, feelings of distress, and provocation types. Development and Psychopathology, 7, 313-322.

Crick, N.R., Casas, J.F., \& Ku, H.-C. (1999). Relational and physical forms of peer victimization in preschool. Developmental Psychology, 35, 376-385.

Crick, N.R, \& Grotpeter, J.K. (1995). Relational aggression, gender and socialpsychological adjustment. Child Development, 66, 710-722.

Cummings, E.M., Iannotti, R.J., \& Zahn-Waxler, C. (1989). Aggression between peers in early childhood: Individual continuity and developmental change. Child Development, 60, 887-895.

Cynader, M., \& Frost, B. (1999). Mechanisms of brain development: Neuronal sculpting by the physical and social environment. In D. Keating \& C. Hertzman (Eds.), Developmental health and the wealth of nations: Social, biological, and educational dynamics (pp. 153-184). New York: Guilford Press.

Dawe, H.C. (1934). An analysis of 200 quarrels of preschool children. Child Development, 5, 139-157.

Day, D.M., Bream, L.A., \& Pal, A (1992). Proactive and reactive aggression: An analysis of subtypes based on teacher perceptions. Journal of Clinical Child Psychology, 21, 210-217.

Diamond, A, Werker, J.F., \& Lalonde, C. (1994). Toward understanding commonalities in the development of object search, detour navigation, categorization, and speech perception. In G. Dawson \& K.W. Fischer (Eds.), Human behavior and the developing brain (pp. 380-426). New York: Guilford Press.

Dishion, T.J. (1990). Peer context of troublesome behavior in children and adolescents. In P.E. Leone (Ed.), Understanding troubled and troublesome youth (pp. 128-153). Beverly Hills, CA: Sage.

Dishion, T.J., McCord, J., \& Poulin, F. (1999). Iatrogenic effects in early adolescent interventions that aggregate peers. American Psychologist, 54, 755764.

Dishion, T.J., Patterson, G.R., Stoolmiller, M., \& Skinner, M.L. (1991). Family, school, and behavioral antecedents to early adolescent involvement with antisocial peers. Developmental Psychology, 27, 172-180.

Dodge, K.A (1986). A social-information-processing model of social competence in children. In M. Perlmutter (Ed.), Minnesota symposium on child psychdogy (Vol. 18, pp. 77-125). Hillsdale, NJ: Erlbaum.

Dodge, K.A (in press). Conduct disorder. In M. Lewis \& AJ. Sameroff (Eds.), Handbook of developmental psychopathology (2nd ed.). New York: Plenum.

Dodge, K., Lochman, J.E., Harnish, J.D., Bates, J.E., \& Pettit, G.S. (1997). Reactive and proactive aggression in school children and psychiatrically impaired chronically assaultive youth. Journal of Abnormal Psychology, 106, 3751.

Dodge, K.A, \& Coie, J.D. (1987). Social information processing factors in reactive and proactive aggression in children's peer groups. Journal of Personality and Social Psychology, 53, 1146-1158.

Dumas, J.E., \& Wahler, R.G. (1985). Indiscriminate mothering as a contextual factor in aggressive-oppositional child behavior: "Damned if you do and damned if you don't". Journal of Abnormal Child Psychology, 13, 1-17.

Eley, T.C., Lichenstein, P., \& Stevenson, J. (1999). Sex differences in the etiology of aggressive and nonaggressive antisocial behavior: Results from two twin studies. Child Development, 70, 155-168.

Elliott, D.S. (1994). Serious violent offenders: Onset, developmental course and termination: The American Society of Criminology 1993 Presidential Address. Criminology, 32, 1-21.

Ellis, L., \& Coontz, P.D. (1990). Androgens, brain functioning, and criminality: The neurohormonal foundations of antisociality. In L. Ellis \& H. Hoffman (Eds.), Crime in biological, social and moral contexts (pp. 162-193). New York: Praeger.

Eron, L.D. (1982). Parent-child interaction, television violence, and aggression of children. American Psychologist, 37, 197-211.

Eron, L.D., \& Huesmann, L.R. (1986). The role of television in the development of prosocial and antisocial behavior. In D. Olweus, J. Block, \& 
M. Ratkie-Iarrow (Eds.), The development of prosocial and antisocial behavior (pp. 285-314). New York: Academic Press.

Eysenck, H.J., \& Gudjonsson, G.H. (1989). The causes and cures of criminality. New York: Plenum.

Farrington, D.P. (1978). The family backgrounds of aggressive youths. In L.A Hersov, M. Bergers, \& D. Shaffer (Eds.), Aggression and antisocial behavior in childhood and adolescence (pp. 73-93). Oxford, UK: Pergamon.

Farrington, D.P. (1986). Age and crime. In M. Tonry \& N. Morris (Eds.), Crime and justice: An annual review of research (Vol. 7, pp. 189-250). Chicago: University of Chicago Press.

Farrington, D.P. (1993). Understanding and preventing bullying. In M. Tonry (Ed.), Crime and Justice: A review of research (Vol. 17). Chicago, IL: University of Chicago Press.

Farrington, D.P. (1998). Individual differences and offending. In M.H. Tonry (Ed.), The handbook of crime and punishment (pp. 241-268). New York: Oxford University Press.

Farrington, D.P., \& Hawkins, J.D. (1991). Predicting participation, early onset and later persistence in officially recorded offending. Criminal Behavior and Mental Health, 1, 1-33.

Farrington, D.P., Loeber, R., Elliott, D.S., Hawkins, D., Kandel, D.B., Klein, M.W., McCord, J., Rowe, D.C., \& Tremblay, R.E. (1990a). Advancing knowledge about the onset of delinquency and crime. In B.B. Lahey \& AE. Kazdin (Eds.), Advances in clinical child psychology (Vol. 13, pp. 283-342). New York: Plenum.

Farrington, D.P., Loeber, R. \& Van Kammen, W.B. (1990b). The long term criminal outcomes of conduct problem boys with or without impulsiveinattentive behavior. In L.N. Robins \& M. Rutter (Eds.), Straight and devious pathways from childhood to adulthood (pp. 62-81). New York: Cambridge University Press.

Fergusson, D.M., Lynskey, M.T., \& Horwood, L.J. (1996). Factors associated with continuity and changes in disruptive behavior patterns between childhood and adolescence. Journal of Abnormal Child Psychology, 24, 533-553.

Feshbach, S. (1970). Aggression. In P.H. Mussen (Ed.), Carmichael's manual of child psychology (Vol. 2) (3rd ed.). New York: Wiley.

Flavell, J.H., \& Miller, P.H. (1998). Social cognition. In D. Kuhn \& R.S. Siegler (Eds.), Handbook of child psychology: Vol. 2. Cognition, perception, and language (pp. 851-898). New York: Wiley.

Goldstein, H. (1995). Multilevel statistical models (2nd ed.). London: Edward Arnold.

Goodenough, F.L. (1931). Anger in young children. Westport, CT: Greenwood.

Gray, J.A (1971). The psychology of fear and stress. London. Weidenfeld \& Nicolson.

Gray, J.A (1982). The neuropsychology of anxiety. New York: Oxford University Press.

Grotpeter, J.K., \& Crick, N.R. (1996). Relational aggression, overt aggression, and friendship. Child Development, 67, 2328-2338.

Haapasalo, J., \& Tremblay, R.E. (1994). Physically aggressive boys from ages 6 to 12: Family background, parenting behavior, and prediction of delinquency. Journal of Consulting and Clinical Psychology, 62, 1044-1052.

Hartup, W.W. (1974). Aggression in childhood. American Psychologist, 29, 336341.

Hartup, W.W., \& deWit, J. (1974). The development of aggression: Problems and perspectives. In J. deWit \& W.W. Hartup (Eds.), Determinants and origins of aggressive behavior, (pp. 595-620). The Hague, Netherlands: Mouton.

Hawkins, J.D., Farrington, D.P., \& Catalano, R.P. (1998). Reducing violence through the schools. In D.S. Elliott, B.A. Hamburg et al. (Eds.), Violence in American schools: A new perspective (pp. 188-216). New York: Cambridge University Press.

Hobbes, T. (1958). Leviathan. Indianapolis, IN: Liberal Arts Press. (Original work published 1651).

Hobbes, T. (1998). De cive. New York: Cambridge University Press. (Original work published 1647).

Hrdy, S.B. (1981). The woman that never evolved. Cambridge, MA: Harvard University Press.

Hrdy, S.B., \& Williams, G.C. (1983). Behavioral biology and the double standard. In S.B. Hrdy \& G.C. Williams (Eds.), Social behavior of female vertebrates. New York: Academic Press.

Huesmann, L.R. (1988). An information processing model for the development of aggression. Aggressive Behavior, 14, 13-24.

Huesmann, L.R. (1998, July). An information processing theory for understanding the interaction of emotions and cognitions in the development and instigation of aggressive behavior. Presidential Address, International Society for Research on Aggression. Ramapo College, NJ.

Huesmann, L.R., \& Eron, L.D. (1986). Television and the aggressive child: A crossnational comparison. Hillsdale, $\mathrm{NJ}$ : Erlbaum.

Huesmann, L.R., Eron, L.D., Guerra, N.G., \& Crawshaw, V.B (1994). Measuring children's aggression with teachers' predictions of peer nominations. Psychological Assessment, 6, 329-336.

Huesmann, L.R., Eron, L.D., Lefkowitz, M.M., \& Walder, L.O. (1984). Stability of aggression over time and generations. Developmental Psychology, 20, 1120-1134.
Huesmann, L.R., \& Miller, L.S. (1994). Long-term effects of repeated exposure to media violence in childhood. In L.R. Huesmann (Eds.), Aggressive behavior: Current perspectives (pp. 153-186). New York: Plenum.

Kagan, J. (1974). Development and methodological considerations in the study of aggression. In J. deWit \& W.W. Hartup (Eds.), Determinants and origins of aggressive behavior (pp. 107-114). The Hague: Mouton.

Keenan, K., \& Shaw, D.S. (1994). The development of aggression in toddlers. A study of low-income families. Journal of Abnormal Child Psychology, 22, 53-77.

Kellam, S.G., Rebok, G.W., Ialongo, N., \& Mayer, L.S. (1994). The course and malleability of aggressive behavior from early first grade into middle school: Results of a developmental epidemiologically-based preventive trial. Journal of Child Psychology and Psychiatry, 35, 259-281.

Lagerspetz, K.M., Björkqvist, K., \& Peltonen, T. (1988). Is indirect aggression typical of females: Gender differences in aggressiveness in 11- to 12-year-old children. Aggressive Behavior, 14, 403-414.

Lahey, B.B., Loeber, R., Quay, H.C., Applegate, B., Shaffer, D., Waldman, I., Hart E.L., McBurnett, K., Frick, P.J., Jensen, P.S., Dulcan, M.K., Canino, G., \& Bird, H.R. (1998). Validity of DSM-IV subtypes of conduct disorder based on age of onset. Journal of the American Academy of Child and Adolescent Psychiatry, 37, 435-442.

Lefkowitz, M.M., Eron, L.D., Walder, L.O., \& Huesmann, L.R. (1977). Growing up to be violent: A longitudinal study of the development of aggression. New York: Pergamon.

Lewis, M., Alessandri, S.M., \& Sullivan, M.W. (1990). Violation of expectancy, loss of control, and anger expressions in young infants. Developmental Psychology, 26, 745-751.

Lochman, J.E. (1992). Cognitive-behavioral intervention with aggressive boys: Three-year follow-up and preventive effects. Journal of Consulting and Clinical Psychology, 60, 426-432.

Locke, J. (1996). Some thoughts concerning education. Indianapolis, IN: Hackett. (Original work published 1693).

Loeber, R. (1988). Natural histories of conduct problems, delinquency, and associated substance use: Evidence for developmental progressions. In B.B. Lahey \& AE. Kazdin (Eds.), Advances in Clinical Child Psychology (Vol. 11, pp. 73-124). New York: Plenum.

Loeber, R., Farrington, D.P., Stouthamer-Loeber, M., \& Van Kammen, W.B. (1998). Antisocial behavior and mental health problems: Explanatory factors in childhood and adolescence. Mahwah, NJ: Erlbaum.

Loeber, R., \& Hay, D.F. (1997). Key issues in the development of aggression and violence from childhood to early adulthood. Annual Review of Psychology, $48,371-410$.

Loeber, R, \& Stouthamer-Loeber, M. (1998). Development of juvenile aggression and violence. Some common misconceptions and controversies. American Psychologist, 53, 242-259.

Loeber, R., Stouthamer-Loeber, M., \& Green, S.M. (1991). Age at onset of problem behaviour in boys, and later disruptive and delinquent behaviours. Criminal Behaviour and Mental Health. 1, 229-246.

Loeber, R., Tremblay, R.E., Gagnon, C., \& Charlebois, P. (1989). Continuity and desistance in boys' early fighting at school. Development and Psychopathology, 1, 39-50.

Lorenz, K. (1966). On aggression. New York: Harcourt, Brace.

Maccoby, E.E., \& Jacklin, C.N. (1974). The psychology of sex differences. Stanford, CA: Stanford University Press.

Maccoby, E.E., \& Jacklin, C.N. (1980). Sex differences in aggression: A rejoiner and reprise. Child Development, 51, 964-980.

Magnusson, D., \& Bergman, L.R. (1988). Individual and variable-based approaches to longitudinal research in early risk factors. In M. Rutter (Ed.), Studies of psychosocial risk: The power of longitudinal data (pp. 45-61). New York: Cambridge Univesity Press.

McCord, J. (1978). A thirty-year follow-up of treatment effects. American Psychologist, 33, 284-289.

McCord, J. (1991). Family relationships, juvenile delinquency, and adult criminality. Criminology, 29, 397-417.

McCord, J. (1992). The Cambridge-Somerville Study: A pioneering longitudinal experimental study of delinquency prevention. In J. McCord \& R.E. Tremblay (Eds.), Preventing antisocial behavior: Interventions from birth through adolescence (pp. 196-206). New York: Guilford Press.

McCord, J., \& Tremblay, R.E. (Eds.). (1992). Preventing antisocial behavior: Interventions from birth through adolescence. New York: Guilford Press.

McGrew, W.C. (1972). An ethological study of children's behavior. New York: Academic Press.

Mills, W. (1899). The nature of animal intelligence and the methods of investigating it. Psychological Review, 6, 262-274.

Moffitt, T.E. (1993). Adolescence-limited and life-course persistent antisocial behavior: A developmental taxonomy. Psychological Review, 100, 674-701.

Moffitt, T.E., Caspi, A, Dickson, N., Silva, P.S., \& Stanton, W. (1996). Childhood-onset versus adolescent-onset antisocial conduct problems in males: Natural history from ages 3 to 18 years. Development and Psychopathology, 8, 399-424.

Murphy, L.B. (1937). Social behavior and child personality. New York: Columbia University Press. 
Nagin, D., \& Tremblay, R.E. (1999). Trajectories of boys' physical aggression, opposition, and hyperactivity on the path to physically violent and non violent juvenile delinquency. Child Development, 70, 1181-1196.

Nagin, D.S., \& Land, K.C. (1993). Age, criminal careers, and population heterogeneity: Specification and estimation of a nonparametric, mixed Poisson model. Criminology, 31, 327-362.

O'Connor, T.G., McGuire, S., Reiss, D., Hetherington, M.E., \& Plomin, R (1998). Co-occurrence of depressive symptoms and antisocial behavior in adolescence: Acommon genetic liability. Journal of Abnormal Psychology, 107, 27-37.

Olds, D., Henderson, C.R., Cole, R, Eckenrode, J., Kitzman, H., Luckey, D., Pettit, L., Sidora, K., Morris, P., \& Powers, J. (1998). Long-term effects of nurse home visitation on children's criminal and antisocial behavior: 15-year follow-up of a randomized controlled trial. Journal of the American Medical Association, 280, 1238-1244.

Olweus, D. (1978). Aggression in the schools. Washington, DC: Hemisphere.

Olweus, D. (1979). Stability of aggressive reaction patterns in males: A review. Psychological Bulletin, 85, 852-875.

Olweus, D. (1993). Bullying at school: What we know and what we can do. Oxford, UK: Blackwell.

Pagani, L., Boulerice, B., Tremblay, R.E., \& Vitaro, F. (1997). Behavioural development in children of divorce and remarriage. Journal of Child Psychology and Psychiatry, 38, 769-781.

Parke, R.D., \& Slaby, R.G. (1983). The development of aggression. In P.H. Mussen (Ed.), Handbook of child psychology: Socialization, personality and social development (Vol. 4, pp. 547-641). New York: Wiley.

Patterson, G.R. (1982). A social learning approach to family intervention: III. Coercive family process. Eugene, OR: Castalia.

Patterson, G.R., Capaldi, D., \& Bank, L. (1991). An early starter model for predicting delinquency. In D.J. Pepler \& K.H. Rubin (Eds.), The development and treatment of childhood aggression (pp. 139-168). Hillsdale, NJ: Erlbaum.

Patterson, G.R., DeBaryshe, B.D., \& Ramsey, E. (1989). A developmental perspective on antisocial behavior. American Psychologist, 44, 329-335.

Patterson, G.R., Dishion, T.J., \& Bank, L. (1984). Family interaction: A process model of deviancy training. Aggressive Behavior, 10, 253-267.

Pepler, D., Craig, W., \& O'Connell, P. (1999). Understanding bullying from a dynamic systems perspective. In A Slater, D. Muir et al. (Eds.), The Blackwell reader in development psychology (pp. 440-451). Malden, MA: Blackwell.

Pitkänen, L. (1969). A descriptive model of aggression and nonaggression with applications to children's behaviour. Jyväskylä Studies in Education, Psychology and Social Research, No. 19. Jyväskylä: University of Juväskylä.

Plomin, R., \& Rutter, M. (1998). Child development, molecular genetics, and what to do with genes once they are found. Child Development, 69, 1223-1242.

Powers, E., \& Witmer, H. (1951). An experiment in the prevention of delinquency: The Cambridge-Somerville youth study. Montclair, NJ: Columbia University Press.

Pulkkinen, L. (1983). Finland: The search for alternatives to aggression. In AP. Goldstein \& M.H. Segal (Eds.), Aggression in global pespective (Vol. 1, pp. 104 144). New York: Pergamon.

Pulkkinen, L. (1987). Offensive and defensive aggression in humans: A longitudinal perspective. Aggressive Behavior, 13, 197-212.

Pulkkinen, L. (1996). Proactive and reactive aggression in early adolescence as precursors to anti- and prosocial behavior in young adults. Aggressive Behavior, 22, 241-257.

Pulkkinen, L., \& Tremblay, R.E. (1992). Patterns of boys' social adjustment in two cultures and at different ages: A longitudinal perspective. International Journal of Behavioural Development, 15, 527-553.

Quetelet, A (1833). Research on the propensity for crime at different ages. Brussels: M. Hayez, Printer to the Royal Academy.

Restoin, A, Montagner, H., Rodriguez, D., Giradot, J.J., Laurent, D., Kontar, F., Ullmann, V., Casagrande, C., \& Talpain, B. (1985). Chronologie des comportements de communication et profils de comportement chez le jeune enfant. In RE. Tremblay, M.A. Provost, \& F.F. Strayer (Eds.), Ethologie et développement de l'enfant (pp. 93-130). Paris: Editions Stock/Laurence Pernoud.

Rousseau, J.-J. (1979). Émile or On education. New York: Basic Books. (Original work published 1762).

Rubin, K.H., Hastings, P., Chen, X., Stewart, S., \& McNichol, L. (1998). Intrapersonal and maternal correlates of aggression, conflict, and externalizing problems in toddlers. Child Development, 69, 1614-1629.

Rubin, K.H., \& Krasnor, L.R. (1986). Social-cognitive and social-behavior perpectives on problem-solving. In M. Perlmutter (Ed.), The Minnesota Symposium on Child Psychology (Vol. 18, pp. 1-68). Hillsdale, NJ: Erlbaum.

Rutter, M. (Ed.) (1996). Genetics of criminal and antisocial behaviour, Chichester, UK: Wiley.

Schwartz, D., Dodge, K.A, \& Coie, J.D. (1993). The emergence of chronic peer victimization in boys' play groups. Child Develoment, 64, 1755-1772.

Schweinhart, L.L., Barnes, H.V., \& Weikart, D.P. (1993). Significant benefits. The High/Scope Perry School Study through age 27. Ypsilanti, NI: High/Scope Press.
Slutske, W.S., Heath, AC., Dunne, M.P., Statham, D.J., Dinwiddie, S.H., Madden, P.A.F., Martin, N.G., \& Bucholz, K.K. (1997). Modeling genetic and environmental influences in the etiology of conduct disorder: A study of 2,682 adult twin pairs. Journal of Abnormal Psychology, 106, 266-279.

Smith, P.K., \& Sharp, S. (1994). School bullying: Insights and perspectives. London: Routledge.

St. Augustine (1960). Confessions. New York: Doubleday.

Strayer, F.F., \& Strayer, J. (1976). An ethological analysis of social agonism and dominance relations among preschool children. Child Develoment, 47, 980988.

Strayer, F.F., \& Trudel, M. (1984). Developmental changes in the nature and function of social dominance among young children. Ethology and Sociobiology, $5,279-295$.

Sully, J. (1895). Studies of childhood. London: Longmans, Green and Co.

Tremblay, RE., Boulerice, B., Harden, P.W., McDuff, P., Pérusse, D., Pihl, R.O., \& Zoccolillo, M. (1996). Do children in Canada become more aggressive as they approach adolescence? In Human Resources Development Canada and Statistics Canada (Eds.), Growing up in Canada: National longitudinal survey of children and youth (pp. 127-137). Ottawa: Statistics Canada.

Tremblay, RE., \& Craig, W. (1995). Developmental crime prevention. In M. Tonry \& D.P. Farrington (Eds.), Building a safer society: Strategic approaches to crime prevention (Vol. 19, pp. 151-236). Chicago: University of Chicago Press.

Tremblay, R.E., Japel, C., Pérusse, D., Boivin, M., Zoccolillo, M., Montplaisir, J., \& McDuff, P. (1999a). The search for the age of "onset" of physical aggression: Rousseau and Bandura revisited. Criminal Behavior and Mental Health, 9, 8-23.

Tremblay, R.E., Kurtz, L., Mâsse, L.C., Vitaro, F., \& Pihl, R.O. (1995). A bimodal preventive intervention for disruptive kindergarten boys: Its impact through mid-adolescence. Journal of Consulting and Clinical Psychology, 63, 560-568.

Tremblay, R.E., LeMarquand, D., \& Vitaro, F. (1999b). The prevention of ODD and CD. In H.C. Quay \& AE. Hogan (Eds.), Handbook of disruptive behavior disorders (pp. 525-555). New York: Kluwer/Plenum.

Tremblay, RE., Loeber, R., Gagnon, C., Charlebois, P., Larivée, S., \& LeBlanc, M. (1991). Disruptive boys with stable and unstable high fighting behavior patterns during junior elementary school. Journal of Abnormal Child Psychology, 19, 285-300.

Tremblay, R.E., Mâsse, L.C., Pagani, L., \& Vitaro, F. (1996). From childhood physical aggression to adolescent maladjustment: The Montréal Prevention Experiment. In RD. Peters \& RJ. McMahon (Eds.), Preventing childhood disorders, substance abuse and delinquency (pp. 268-298). Thousand Oaks, CA: Sage.

Tremblay, R.E., Pihl, R.O., Vitaro, F., \& Dobkin, P.L. (1994). Predicting early onset of male antisocial behavior from preschool behavior. Archives of General Psychiatry, 51, 732-738.

Vitaro, F., Brendgen, M., \& Tremblay, R.E. (1999). Prevention of school dropout through the reduction of disruptive behaviors and school failure in elementary school. Journal of School Psychology, 37, 205-226.

Vitaro, F., Brendgen, M., \& Tremblay, R.E. (in press). Preventive intervention: Assessing its effects on the trajectories of delinquency and testing for mediational processes. Applied Developmental Science.

Vitaro, F., Gendreau, P.L., Tremblay, R.E., \& Oligny, P. (1998). Reactive and proactive aggression differentially predict later conduct problems. Journal of Child Psychology and Psychiatry, 39, 1-9.

Vitaro, F., Tremblay, R.E., Kerr, M., Pagani-Kurtz, L., \& Bukowski, W.M. (1997). Disruptiveness, friends' characteristics, and delinquency in early adolescence: A test of two competing models of development. Child Development, 68, 676-689.

Wahler, R.G., \& Dumas, J.E. (1986). Maintenance factors in coercive motherchild interactions: The compliance and predictability hypothesis. Journal of Applied Behavior Analysis, 19, 13-22.

Walters, R.H., \& Parke, R.D. (1964). Social motivation, dependency, and susceptibility to social influence. In L. Berkowitz (Ed.), Advances in experimental social psychology (Vol. 1). New York: Academic Press.

Wasserman, G.A, \& Miller, L.S. (1998). The prevention of serious and violent juvenile offending. In R. Loeber \& D.P. Farrington (Eds.), Serious and violent juvenile offenders: Risk factors and successful interventions (pp. 197-247). Thousand Oaks, CA: Sage.

Webster-Stratton, C. (1998). Preventing conduct problems in Head Start children. Journal of Consulting and Clinical Psychology, 66, 715-730.

Weikart, D.P., \& Schweinhart, L.J. (1992). High/Scope preschool program outcomes. In J. McCord \& R.E. Tremblay (Eds.), Preventing antisocial behavior: Interventions from birth to adolescence (pp. 67-86). New York: Guilford Press.

Willett, J.B., \& Sayer, AG. (1994). Using covariance structure analysis to detect correlates and predictors of individual change over time. Psychological Bulletin, 116, 363-381.

Zelazo, P.D., Helwig, C.C., \& Lau, A (1996). Intention, act, and outcome in behavioral prediction and moral judgment. Child Development, 67, 24782492. 